DOI 10.37882/2223-2982.2021.10.23

\title{
СОЦИОЛИНГВИСТИЧЕСКИЕ ОСОБЕННОСТИ ПОДЬЯЗЫКА ДЕЛОВОГО ОБЩЕНИЯ (НА ПРИМЕРЕ КОРПОРАТИВНОГО ЖАРГОНА)
}

\section{SOCIOLINGUISTIC FEATURES \\ OF THE SUBLANGUAGE OF BUSINESS COMMUNICATION (ON THE EXAMPLE OF BUSINESS JARGON)}

\section{O. Morozova}

A. Yakhina

Summary: The article defines the status and significance of the professional sublanguage in general and the sublanguage of business communication in particular; the latter is regarded as one of the components of the professional language system. It also reveals the features of corporate jargon, which determines the belonging of its carriers to a particular society, obvious advantages and disadvantages of its use are also traced.

Keywords: sociolect, society, sociolinguistics, language of business communication, professional sublanguage, business jargon.
$\Gamma$ лобализация общества диктует вариации в социуме и языке, что в свою очередь привлекает внимание к исследованию языка, который функционирует в разнообразных областях. Возникает острая необходимость исследования подъязыка как составного компонента общей системы наряду с формированием профессиональной коммуникации. Профессиональный подъязык - это функциональная модификация общелитературного языка; в то же самое время это самостоятельное языковое явление, которое нужно рассматривать внутри языковой системы общенационального языка.

Как известно, социально-профессиональный диалект - это вариация языка общения, которая связана не территориально, а реализуется в том или ином общественном или профессиональном окружении. Социально-профессиональные диалекты неисчислимы. Например, В.В. Колесов в своем произведении «Язык города» анализирует «язык дворянства», «язык чиновников», «язык военных», «профессиональный сленг», «воровское арго», «жаргон купцов», «речь взрослого населения (женщин, мужчин)», «сленг молодежи». В основном рассматриваются социальные диалекты, используется возрастная градация (сленг молодежи и взрослого населения) и учитывается половая дифференциация («женская и мужская речь»).
Морозова Ольга Алексеевна

К.филол.н., старший преподаватель, Елабужский институт Казанского федерального университета

Olga22006@yandex.ru

яхина Альбина Мухаметдиновна

К.филол.н., старший преподаватель, Елабужский институт Казанского федерального университета zam_albina@mail.ru

Аннотация: В данной статье определяется статус и значимость профессионального подъязыка в целом и подъязыка делового общения в частности; последний рассматривается как один из компонентов профессиональной языковой системы. Также раскрываются особенности корпоративного жаргона, определяющего принадлежность его носителей к определенному социуму, прослеживаются очевидные преимущества и недостатки его использования.

Ключевые слова: социолект, социум, социолингвистика, язык делового общения, профессиональный подъязык, корпоративный жаргон.

Если территориальные диалекты могут отличаться друг от друга и от иных разновидностей разговорного и литературного языка на всех ярусах языкового строя, то социально-профессиональные диалекты имеют отличия только на ярусе лексики и фразеологии. А прочие особенности у них те же, что и у всех других разновидностей разговорного языка. Это дает основание считать, что главное в социально-профессиональном диалекте - особый словарь. Профессиональных жаргонов может быть столько же сколько и профессий [цит. по 6]. Однако наша задача - не описание каждого конкретного социально-профессионального диалекта, а общая характеристика особенностей подъязыка делового общения.

Профессиональная активность представляет собой особую среду социальной функциональности человечества, которая оставляет след во всех сферах его жизнедеятельности. Под профессиональной активностью понимают не только собственно трудовую деятельность, но и конкретную организационную цивилизацию, социальное содружество профессионалов, самоопределение представителей профессиональной среды [5].

Главная цель социолингвистики заключается в исследовании социолектов как сравнительно стабильной, неизолированной, сформированной и упорядоченной системы языка, которой пользуется профессиональное 
и социальное единство или группа людей. Интенсивное возникновение социолектов обуславливается языковой презентацией социальной разнообразности общества, их роль предопределяется экстралингвистическими факторами, характерными чертами социального существования социума. С развитием общества углубляется его профессиональная дифференциация. Таким образом, социолект выступает как «совокупность языковых кодов, которыми владеют индивиды, объединенные каким-либо признаком» [3], главным из которых является вид деятельности. По мнению ученых в настоящее время профессиональные социолекты возникают и формируются в таких высокоразвитых функциональных областях, как космонавтика, нефтедобыча, биотехнология, деловая сфера. Именно они обладают на данный момент общественным авторитетом [4].

Профессиональный язык - это не язык в полном смысле слова, так как, используя только профессиональные единицы, невозможно составить полноценное высказывание. Для профессионального языка характерно ограничение сферы коммуникации специальной сферой. Профессиональный язык имеет специфический грамматический строй, его отличительной чертой является лексико-фразеологический состав. Профессиональный язык - более узкое понятие, чем литературный язык, так как ему свойственны преимущественно гносеологическая, когнитивная, эпистемическая, информационно-логическая, интеллектуально-коммуникативная функции. Профессиональный язык направлен на достижение эффективного профессионального направленного общения специалистов. Языковые средства, используемые в определенной сфере, составляют систему, в которой понятия объединены логическими отношениями подчинения и соподчинения. Большинство ученых рассматривает профессиональный язык как терминологическую систему, ядром которой является терминология. В терминосистему входит также некодифицированный лексико-фразеологический состав, так как именно он задействован в развивающихся сферах деятельности.

Профессиональный сленг используется людьми, занятыми непосредственно на производстве; их труд зачастую примитивен, и соответственно им не нужно проходить подготовку и иметь специальное образование. Представители администрации, руководители, а также сотрудники, занятые в деловой сфере, маркетинге, менеджменте, информационной технологии преимущественно используют в своей речи терминологическую лексику.

Корпоративная культура организации и ее значимость для функционирования всей организационной системы в целом все чаще принимается во внимание современными руководителями. В последнее десятилетие производственная сфера общения значительно услож- нилась и дифференцировалась. Широко распространены экономическая, управленческая, коммерческая, правовая сферы профессиональной деятельности, что обусловливает необходимость владения специалистами навыками профессиональной культуры как значимым компонентом профессиональной межкультурной коммуникации.

Деловая коммуникация в настоящее время становится довольно перспективным научно-практическим направлением междисциплинарного и комплексного характера. Это межличностная межкультурная зона профессиональной коммуникации, которая предполагает перцептивный, коммуникативный и интерактивный уровни поведения, определяемая прагмалингвистическими (информативность, регулятивность, имплицитность, экспрессивность) и прагмапсихологическими (заинтересованность, конфликтность, взаимопонимание и понимание) характеристиками общения [1].

Построение делового общения осуществляется на основе определенных, принятых в деловой среде правил поведения. Культура деловых коммуникаций представляет собой совокупность традиций, обычаев, социальных норм, правил, регулирующих поведение людей в сфере деловых коммуникаций. В.И. Добреньков и А.И. Кравченко [2]. С точки зрения набора правил, культура в деловой среде подразумевает соблюдение этических норм нравственного, справедливого делового общения и использование правил делового этикета. Сюда же относится поведение, основанное на умении корректно высказываться и хорошо слушать, понимать партнеров, клиентов, коллег по работе, как в индивидуальном общении, так и в общении с группой и с массовой аудиторией, а также поведение, связанное со способностью выстраивать необходимые взаимоотношения, справляться с возникающими барьерами, поддерживать уже установленные деловые отношения. Данные компоненты часто взаимосвязаны и выступают в совокупности, например, успешное выстраивание взаимоотношений предполагает умение слушать, адекватно понимать других людей и объясняться в доброжелательной и доступной форме.

Таким образом, регламентированность, подчиненность установленным правилам и ограничениям выступают характерной чертой деловой коммуникации, что обуславливается типом делового общения, формальными условиями взаимодействия, высокой степенью официальности, конкретными целями и задачами, особеннос тями письменной коммуникации, национальнокультурными традициями и общественными нормами поведения.

Однако другой стороной делового общения, а также корпоративной культуры, является коммуникация полуофициального или неофициального регистра как 
во временно замкнутом, так и в относительно открытом сообществе (офис, отдел, исследовательская группа, команда) с целью не только упростить общение внутри микросоциума и за его пределами, но и ограничить проникновение непосвященных извне, что нередко проявляется в использовании корпоративного жаргона.

Корпоративный жаргон играет особую роль в формировании корпоративной культуры. Однако следует отметить, что на сегодняшний день не существуют однозначного отношения к использованию данного жаргона в деловой среде. Несмотря на частые высказывания критического характера относительно сомнительной ценности и неуместности употребления жаргонизмов в речи специалистов, большинство руководителей благосклонно относятся к широкому употреблению подчиненными корпоративного сленга.

Можно выделить следующие преимущества использования современного корпоративного жаргона:

1. корпоративный жаргон отражает принадлежность его носителя к определенному кругу, благодаря чему сотрудник чувствует свою значимость, защищенность и желание вносить вклад в общее дело; профессиональный язык, используемый в разных компаниях, обладает отличиями, что дает возможность сотруднику с помощью языка почувствовать себя частью особой, отличной от других команды;

2. жаргонная лексика служит созданию благоприятной атмосферы в коллективе, непринужденного общения; она также, наряду с кличками, шутливыми названиями и прозвищами, в значительной степени снимает напряжение и оживляет канцелярский язык;

3. использование жаргонизмов ускоряет и облегчает работу коллектива. В ходе ежедневного общения на одни и те же темы, сотрудники стремятся сократить или урезать часто употребляемые профессиональные слова в целях экономии времени и энергии;

4. в столь динамичных, современных условиях знания и язык постоянно обновляются, соответственно становятся популярными новые и модные слова-жаргонизмы. Непонятные слова подталкивают человека к самообразованию и постоянному повышению уровня знаний;

5. международная корпоративная лексика (в основном с положительной оценочностью) широко используется в PR-технологиях для создания положительного образа компании. Яркие, меткие жаргонизмы оказывают влияние на ассоциативное мышление человека и потому действуют эффективно;

6. жаргонизмы часто содержат эмотивую информацию и несут более меткий экспрессивный заряд, позволяя собеседникам эффектно и ярко выражать свои мысли;

7. деловой жаргон предлагает готовые выражения или клише без необходимости придумывать различные способы объяснения понятий.

Однако несмотря на очевидные преимущества жаргонной лексики многие западные топ-менеджеры и консультанты рекомендуют отказаться или хотя бы ограничить его применение в силу ряда причин. Недостатками использования корпоративного жаргона являются следующие:

1. офисный жаргон считается вульгарным, снобистским; значение некоторых жаргонизмов является малопонятным или неясным, особенно для новичков или посторонних;

2. использование длинных, сложных или неясных слов, сокращений, эвфемизмов и акронимов может затруднять восприятие и понимание;

3. нередко корпоративный жаргон употребляется сотрудниками для того, чтобы произвести ложное впечатление и скрыть за непонятными фразами собственную некомпетентность; либо он используется вынужденно, чтобы не отставать от коллег.

4. эта лексика имеет фамильярную окраску и снижает статус переговоров или совещаний;

5. деловой жаргон может быть причиной дистанцирования, поскольку некоторые слушатели могут почувствовать себя исключенными, не понимая всех используемых выражений и модных слов, особенно при их резком и быстром звучании.

Решение в столь неоднозначном отношении к использованию корпоративного жаргона видится в его умеренном и адекватном использовании. Корпоративный жаргон является удобным, простым и экспрессивным инструментом общения. Практически каждая отрасль сегодня обладает огромным количеством специализированных слов, обозначающих те или иные устройства и процессы. Жизненный цикл профессионализмов зависит от жизненного цикла самих явлений, которые они обозначают.

В заключение следует отметить, что деловая коммуникация является одним из самых массовых видов общения людей в социуме. При анализе языка делового общения важно учитывать социальные и статусные роли, выступающие в качестве стилеобразующих критериев. Неоднородный характер деловой речи в стилистическом плане является источником разнообразия речевых ситуаций делового общения, которые в зависимости от условий коммуникации обусловливают нормы поведения, речевые формы и речевой этикет.

Таким образом, важная цель социолингвистики заключается в исследовании социальной дифференциа- 
ции языка, в результате которой возникают социолекты, позволяющие полно проследить взаимоотношения языка и общества. Следовательно, изучение социолектов становится все более актуальным в связи с влиянием профессиональных языков на формирование общенационального языка.

\section{ЛИТЕРАТУРА}

1. Басова А.И. Взаимодействие вербальных и невербальных средств коммуникации в межкультурном деловом общении / А.И. Басова. - Текст : электронный // Язык и межкультурная коммуникация: материалы II международной научной конференции 12-мая-2009 Вильнюсский педагогический университет (Литовская Республика) - 2009. - URL: https:/elib.bsu.by/bitstream/123456789/147815/1/Взаимодействие\%20вербальных\%20и\%20невербальных\%20средств\%20коммуникации\%20в\%20межкультурном\%20деловом\%20общении.pdf

2. Добреньков В.И., Кравченко А.И. Социология, учебник для студентов социологических факультетов, отделений и кафедр, преподавателей социологии и аспирантов, а также научной общественности, интересующейся самой интересной и сложной наукой об обществе. / В.И. Добреньков, А.И. Кравченко. Текст : непосредственный // Москва ИНФРА-М 2001. - 624 с.

3. Ерофеева Е.В. К вопросу о соотношении понятий НОРМА и УзУС / Е.В. Ерофеева. - Текст : непосредственный // Проблемы социо- и психолингвистики: Сб. ст. Перм. ун-т. - Пермь, 2003. -Вып.2. - С. 3-8.

4. Крысин Л.П. Проблемы социальной и функциональной дифференциации языка / Л.П. Крысин. - Текст : непосредственный // // Современный русский язык: Социальная и функциональная дифференциация. - М.: Ин-т русского языка им. В.В. Виноградова РАН. - 2003. - 535 с.

5. Малюга Е.Н. Основные характеристики профессионального языка / Е.Н. Малюга. - Текст : непосредственный // Вестник Самарского государственного университета. - 2011г. - С.133-138.

6. Польская С.С., Библиотека Института языкознания РАН: специальность 10.02.20 «Теория языка», Структура и функционирование профессионального социолекта: на материале английского языка: диссертация на соискание ученой степени кандидата филологических наук / Светлана Сергеевна Польская; Москва 2011. - 233 с. - Библиогр.: с. 164-173. -URL: https://www.dissercat.com/content/struktura-i-funktsionirovanie-professionalnogo-sotsiolekta - Teкст: электронный.

○ Морозова Ольга Алексеевна (Olga22006@yandex.ru), Яхина Альбина Мухаметдиновна (zam_albina@mail.ru).

Журнал «Современная наука: актуальные проблемы теории и практики»

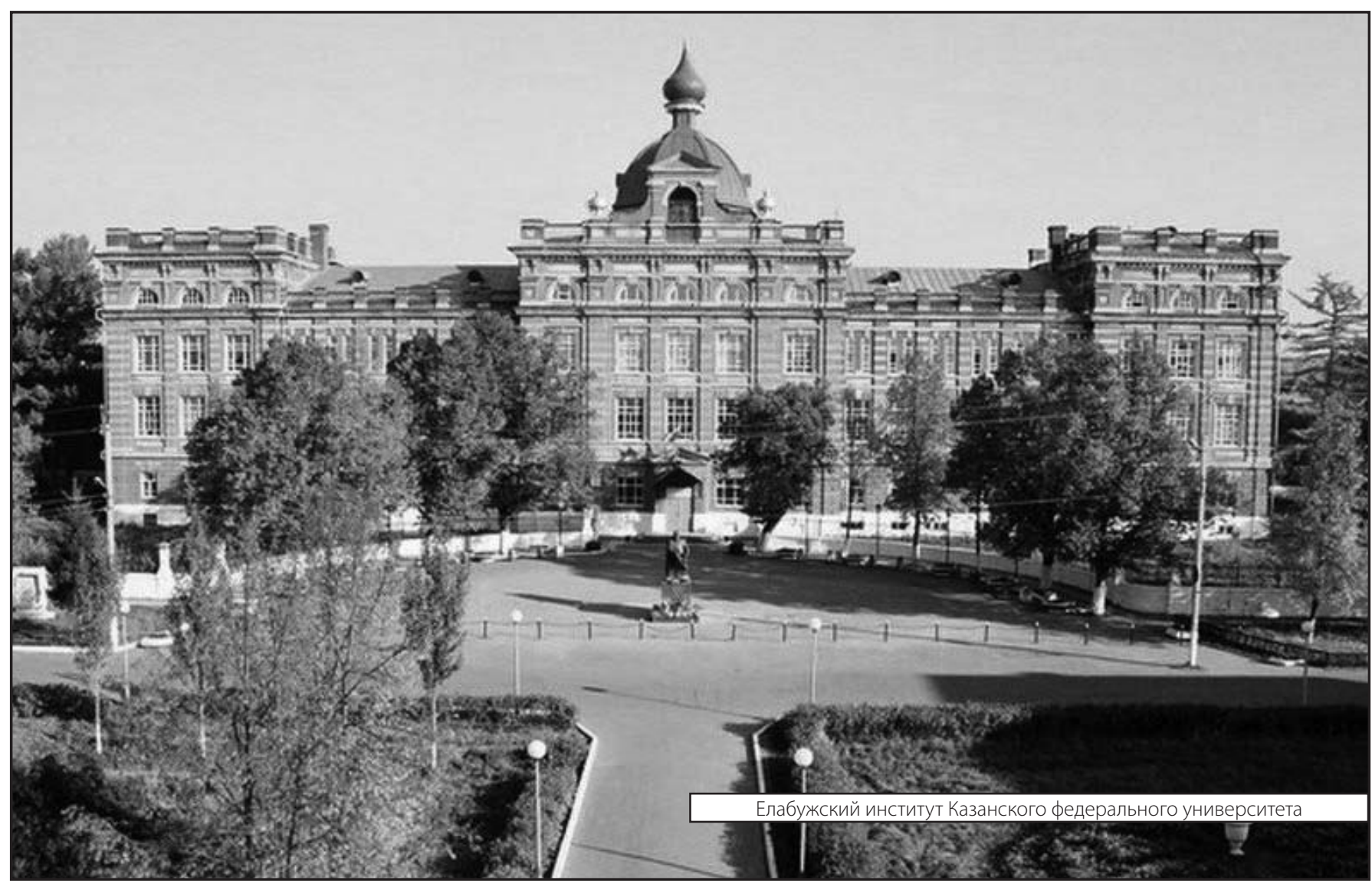

